\title{
PLURALISME HUKUM NEGARA
}

\author{
FAHMI AGUSTA \\ fahmiagusta12@gmail.com \\ 2010003600075 \\ UNIVERSITAS EKASAKTI
}

\section{A. PENDAHULUAN}

Persitegangan antara hukum rakyat dengan hukum negara telah terjadi sejak zaman pendudukan kolonial di Indonesia dan niscaya terjadi pada negara-negara yang terbentuk atas berbagai suku bangsa dengan keragaman budayanya. Persitegangan hukum yang berbeda tersebut tidak jarang berujung pada konflik horizontal maupun vertikal. Ketidakharmonisan hukum rakyat dan negara mengemuka sebagai akibat dari kebijakan pembangunan hukum nasional yang mentransplantasikan hukum yang 'asing' dengan berbagai cara kepada masyarakat yang sejatinya mempunyai hukumnya sendiri. Kata asing dalam hal ini dapat dimaknai dalam dua pengertian, di satu sisi 'asing' dapat bersumber dari hukum kaum penjajah yang diterapkan di daerah koloni, dan di sisi lain hukum yang 'asing' itu adalah hukum nasional yang menjadi produk dari unifikasi dan modernisasi hukum, yang mana dua hal tersebut secara langsung maupun tidak menyingkirkan keragaman hukum rakyat atau anasir sistem hukum yang ada di luar sistem hukum negara/nasional.

Salah satu contoh konflik hukum yang nyata dan sekaligus contoh yang berulang dikemukakan adalah konflik hukum adat dan hukum negara. Undang-undang No. 5 Tahun 1960 (UU Pokok Agraria) dengan jelas memberikan pengakuan terhadap hak masyarakat hukum adat dalam penguasaan tanah dan SDA, tetapi masih ada regulasi lain yang menegasikan prinsip tersebut, UU Kehutanan (UU No. 41 Tahun 1999) misalnya yang mengakui keberadaan hutan adat, akan tetapi UU tersebut menempatkan hutan adat sebagai bagian dari hutan negara. Konflik sistem hukum tersebut tidak jarang berujung pada konflik horizontal maupun vertikal dan menggambarkan bahwa sesungguhnya terdapat gap atau kesenjangan antara pembentuk hukum (institusi negara) dengan pengemban hukum (masyarakat). Konflik demikian terkadang juga menjadi penyebab mandulnya hukum negara dalam pelaksanaannya. Hal ini seolah menegaskan bahwa munculnya penolakan terhadap hukum negara bukan sekedar persoalan keterbatasan pemahaman atau ketidaksadaran hukum masyarakat, tetapi lebih dari itu adalah karena ketidaksediaan rakyat menaati hukum yang berbeda dengan keseharian mereka.

Beranjak dari kondisi tersebut, muncul pertanyaan apakah yang dapat dilakukan untuk mendamaikan kedua hukum tersebut atau setidaknya mempersempit kesenjangan diantara kedua hukum itu. Menjawab pertanyaan tersebut, berbagai upaya telah dilakukan bahkan sejak masa kolonial, secara substansi hukum negara mengakui keragaman hukum yang hidup dalam keseharian masyarakat, dan secara strategi pembangunan hukum, negara harus menitikberatkan pengenalan hukum pada masyarakat ketimbang memaksakan keberlakuan hukum negara tersebut. Dalam konteks ini lah, pendekatan pluralisme hukum dalam pembentukan hukum nasional dan pengenalan hukum menjadi amat penting.

Isu maupun kajian seputar pluralisme hukum bukan isu baru ataupun ranah studi baru di Indonesia. Secara sederhana, pluralisme hukum hadir sebagai kritikan terhadap sentralisme dan positivisme dalam penerapan hukum kepada rakyat. Terdapat beberapa jalan dalam memahami 
pluralisme hukum. Pertama, pluralisme hukum menjelaskan relasi berbagai sistem hukum yang bekerja dalam masyarakat. Kedua, pluralisme hukum memetakan berbagai hukum yang ada dalam suatu bidang sosial. Ketiga, menjelaskan relasi, adaptasi, dan kompetisi antar sistem hukum. Ketiga, pluralisme hukum memperlihatkan pilihan warga memanfaatkan hukum tertentu ketika berkonflik. Dari tiga cara pandang tersebut dan masih banyak cara pandang lainnya, secara ringkas kita bisa katakan bahwa pluralisme hukum adalah kenyataan dalam kehidupan masyarakat. Senada dengan itu, meminjam ungkapan dari Brian Z. Tamanaha, legal pluralism is everywhere. Ungkapan ini menegaskan bahwasanya di area sosial keragaman sistem normatif adalah keniscayaan. Namun, hal menarik tentang pluralisme hukum bukan hanya terletak pada keanekaragaman sistem normatif tersebut, melainkan pada fakta dan potensi untuk saling bersitegang hingga menciptakan ketidakpastian. Ketidakpastian ini menjadi salah satu titik lemah yang "diserang" dari pluralisme hukum, walaupun hal ini tidak sepenuhnya benar karena permasalahan pokok dari potensi konflik tersebut adalah adanya relasi yang asimetris dari sistem normatif tersebut.

Berjalinan dengan itu, John Griffiths mengemukakan konsep pluralisme hukum yang lemah (weak pluralism) dan pluralisme hukum yang kuat (strong pluralism). Pluralisme hukum disebut sebagai pluralisme hukum yang lemah ketika negara mengakui kehadiran anasir sistem hukum lain di luar hukum negara, tetapi sistem-sistem hukum non negara tersebut tunduk keberlakuannya di bawah hukum negara. Sementara itu, pluralisme hukum yang kuat hadir ketika negara mengakui keberadaan hukum non negara dan sistem hukum tersebut mempunyai kapasitas keberlakuan yang sama dengan hukum negara.

Pandangan Tamanaha dan Griffiths di atas pada akhirnya membawa kita pada ulasan tentang kelemahan dan kritik terhadap pluralisme hukum. Ketika ketimpangan dominasi kekuasaan diantara eksponen berbagai sistem hukum tersebut tetap langgeng, maka pluralisme hukum bisa jadi sebatas mitos atau delusi, dan terciptanya ketidakpastian hukum bukan tidak mungkin terjadi apabila pluralisme hukum membuka ruang pengakuan bagi setiap sistem hukum lain di luar hukum negara tanpa adanya batasan yang jelas. Dua hal ini setidaknya memberikan 'peringatan' pada kita bahwa pluralisme hukum yang semula hadir untuk mengkritik juga tidak sepi dari kritikan. Pada bagian berikut ini akan dibahas ihwal kritik atas pluralisme hukum dan kaitannya dengan permasalahan yang ada pada konteks pembangunan sistem hukum di Indonesia.

Sebagaimana pemaparan sebelumnya, pluralisme hukum boleh dikatakan menjadi jawaban terhadap kekurangan yang ditemui pada cara pandang sistem hukum nasional di Indonesia yang cenderung sentralistik. Hal ini bisa dilihat dari beberapa kebijakan dan ketentuan peraturan perundang-undangan yang mengandung ide pluralisme hukum di dalamnya. Contoh klasik adalah UU Agraria yang secara jelas menyebut pengakuan terhadap hak masyarakat hukum adat dan tanah ulayat. Pada perkembangannya, tidak saja di tingkat nasional tetapi juga di tingkat daerah juga bermunculan peraturan daerah yang mencoba mengakui atau mengintegrasikan keberagaman hukum di tingkat lokal seiring dengan pemberlakuan otonomi daerah dan otonomi khusus. Sebagai contoh, maraknya pembentukan perda syariah di

daerah, qanun di Aceh, dan pembentukan lembaga-lembaga adat yang diakui sebagai media penyelesaian sengketa adat.

Selintas lalu, situasi tersebut dapat diapresiasi sebagai sebuah terobosan pembaruan hukum dan upaya untuk mengakomodasi keragaman normatif yang ada di masyarakat. Namun demikian, dalam praktiknya dijumpai pelbagai permasalahan yang membawa kita pada kondisi yang 
dilematis dan keadaan pluralisme hukum yang lemah sebagaimana pandangan Griffiths. Pasalnya, keberadaan hukum 'rakyat' atau hukum adat tersebut bergantung pada pengakuan hukum negara. Lebih jauh dari itu, apa yang disebut dengan hukum adat adalah konstruksi oleh hukum negara, dengan demikian hukum adat bukanlah hukum yang hidup dan dipercayai oleh masyarakat melainkan hukum 'adat' yang dirumuskan oleh hukum negara. Kondisi ini tidak jauh berbeda dengan keberadaan lembaga adat tersebut, dimana hasil dari penyelesaian lembaga adat tidak jarang dimentahkan oleh lembaga peradilan atau lembaga ini nyaris tidak bertaji dalam menyelesaikan sengketa adat di lingkungan masyarakat adat sebab lembaga adat tersebut tidak mempunyai kapasitas mengeksekusi keputusan layaknya institusi peradilan. Lain halnya dengan perda syariah, yang mana di beberapa daerah perda tersebut mengundang penolakan keras oleh masyarakat di daerah yang bersangkutan. Pasalnya, ketentuan dalam perda-perda demikian bertolak belakang dengan ketentuan undang-undang yang secara hierarki harus selaras, bahkan pada titik tertentu perda tersebut dinilai bertentangan dengan HAM.

\section{B. PEMBAHASAN}

Pluralisme hukum dapat didefinisikan sebagai keberadaan mekanisme-mekanisme hukum yang berbeda di dalam suatu masyarakat. Sebagai contoh, di afrika pada masa penjajahan, orang Afrika diatur oleh hukum adat, orang Eropa yang menetap di wilayah tersebut diatur dengan hukum tertulis, sementara diplomat yang sedang bertandang di negeri tersebut memiliki kekebalan hukum dan memperoleh keuntungan dari mekanisme hukum yang tidak berlaku kepada rakyat di negeri tersebut.

Sementara itu, Barry Hooker (1975) mendefinisikan pluralisme hukum sebagai interaksi antara dua jenis hukum atau lebih. Bagi Hooker, sistem pluralisme hukum yang ada di dunia saat ini merupakan dampak dari menyebarnya sistem hukum tertentu ke luar wilayah asalnya. Contohnya adalah Indonesia pada masa penjajahan belanda sistem hukum Belanda diperkenalkan di Nusantara dan kemudian diterima sebagai hukum Indonesia setelah kemerdekaan.

Terdapat dua jenis pluralisme hukum. Yang pertama adalah "pluralisme hukum negara", yaitu ketika dua sistem norma berlaku sebagai hukum negara. Contohnya adalah hukum adat dan hukum tertulis yang berlaku sebagai hukum negara di Afrika pada masa penjajahan. Sementara itu, jenis pluralisme hukum yang kedua adalah deep legal pluralism, yaitu ketika terdapat tatanan norma di luar hukum negara yang berlaku di masyarakat.

\section{1) Konsep-konsep Pluralisme Hukum}

Kajian mengenai hukum dapat ditinjau dari berbagai dimensi, baik dalam konteks yang dibuat oleh negara, maupun dalam konteks sosial, budaya, ekonomi dan politik. Secara terbatas hukum dikaitkan dengan hukum negara, khususnya undang-undang (law in the book).

Para Antropolog menangkap hukum sebagai suatu acuan normative yang luas dan terus hidup dan berkembang secara dinamis (living law), meliputi tidak hanya hukum negara, tetapi juga sistem norma di luar negara, ditambah pula dengan segala proses dan actor yang ada di dalamnya. Hukum tidak hanya berisi konsepsi normative: hal-hal yang dilarang dan dibolehkan, tetapi juga berisi konsep kognitif.

Pertemuan atau interaksi antara pengertian hukum atau bahkan sistem hukum yang satu dengan yang lainnya merupakan suatu kajian tersndiri yang menarik di dalam ilmu hukum yang 
sering disebut dengan kajian pluralisme hukum. Pluralisme hukum barangkali telah menjadi salah satu istilah yang paling menarik dan paling kontroversial dalam literature teori hukum, antropologi hukum dan sosiologi hukum.

Tammanaha bahkan menyatakan selama ini istilah pluralisme hukum (legal pluralism) telah dianggap sebagai konsep kunci dalam kajian-kajian hukum post-modern. Pluralisme hukum sangat membantu memberikan penjelasan terhadap kenyataan adanya keteraturan hukum (legal order) yang diproduksi negara. Menurut Griffiths, situasi pluralisme hukum berkembang pesat seiring dengan laju pluralisme sosial. Karena itu, adalah keniscayaan, bahwa masyarakat yang plural akan melahirkan tata hukum yang plural. Sebaliknya, pemaksaan sentralisme hukum adalah pekerjaan sia-sia karena sifatnya asosial.

Dalam konteks ini, pluralisme hukum merupakan konsep yang menujukkan kondisi, bahwa lebih dari satu sistem hukum yang ada dan berlaku bersamaan atau berinteraksi dalam mengatur berbagai aktivitas dan hubungan manusia di suatu tempat.

Secara teoretik, pemahaman tentang pluralisme hukum oleh Keebet von Benda adalah untuk membedakan dengan pemahaman pluralitas hukum. Berbagai sistem hukum yang di dalam suatu wilayah, bukan hanya sekedar hidup berdampingan tanpa melakukan interaksi. Bila dalam lapangan sosial yang sama hidup berdampingan lebih dari satu sistem hukum namun tidak saling melakukan interaksi maka keadaan tersebut dinamai plurality of law (pluralitas hukum). Namun bila antar sistem hukum tersebut melakukan interaksi, maka keadaan tersebut dinamai dengan legal pluralism (pluralisme hukum).

Berbagai tulisan dalam Mobile People Mobile Law, menggambarkan tentang mata rantai interaksi yang menghubungkan para actor transnasional, nasional dan lokal yang melakukan negoisasi dalam arena multisited dan didasarkan pada relasi-relasi kekuasaan. Sangat penting untuk melihat relasi kekuasaan itu menstrukturkan interaksi, dan bagaimana interaksi itu diproduksi dan diubah oleh aktor-aktor tersebut

Bagi Griffiths, salah satu bentuk dari pluralisme hukum itu dibagi 2 macam, yaitu strong legal pluralism dan weak legal pluralism. Suatu kondisi dapat dikatakan strong legal pluralism jika masing-masing sistem hukum yang beragam itu otonom dan eksistensinya tidak tergantung kepada hukum negara. Jika keberadaan pluralisme hukum itu bergantung kepada pengakuan dari hukum negara maka kondisi seperti itu disebut dengan weak legal pluralism Dengan kata lain, pluralisme hukum yang kuat karena ada situasi ketika antar berbagai sistem hukum melangsungkan interaksi yang saling tidak mendominasi alias sederajat.

Individu atau kelompok yang hidup dalam lapangan atau wilayah sosial tertentu bebas memilih salah satu hukum dan bebas untuk mengkombinasikan berbagai sistem hukum dalam melangsungkan aktivitas keseharian atau untuk menyelesaikan sengketa. Pluralisme hukum yang lemah adalah salah satu sistem hukuim memiliki posisi superior di hadapan dengan sistem hukum lainnya. Individu atau kelompok lebih sering menggunakan salah satu sistem hukum karena tekanan.

Selanjutnya, berbagai konsep itu dikembangkan oleh Simarmata, pluralisme juga menemukan relasi antar berbagai sistem hukum tersebut, bisa saja berupa diffusi, kompetisi atau koorporatif. Misalnya hukum negara tidak selalu menyangkal hukum adat, namun juga mengakui dan mengakomodasi keberadaan hukum adat dan sebaliknya. Pluralisme hukum bukan hanya berkembang dalam hal wilayah atau objek kajian tetapi juga berkembang dengan cara lain, yakni mendetailkan atau menajamkan dirinya. Ada beberapa pemikiran seperti itu, di antaranya (1) strong legal pluralism and weak legal pluralism; (2) mapping of law; dan (3) critical legal pluralism.

Pluralisme hukum mengandaikan adanya pilihan dalam penerapan hukum. Pilihan terhadap sebuah perilaku dipelajari, khususnya dalam kasus-kasus konflik. Jarang sekali hanya ada satu 
kemungkinan dalam hal yang berususan dengan konflik. Selain ada peradilan yang resmi oleh aparat pengadilan dari negara, biasanya ada pilihan yang sangat luas, seperti penengah dan juru runding.

Dibandingkan dengan literature lain, sengketa disebut perkara. Terkadang disebut juga dengan beracara atau prosedur. Beracara, yaitu tata cara penyelesaian sengketa. Dalam sistem hukum negara di Indonesia, penyelesaian sengketa dapat dilakukan melalui litigasi dan non litigasi yang diatur dalam UU No. 48 Tahun 2009 tentang Kekuasaan Kehakiman, mengatur penyelesaian melalui peradilan umum, peradilan militer, peradilan agama, peradilan Tata Usaha Negara, dalam peradilan khusus: seperti peradilan anak, peradilan negara, peradilan pajak, peradilan penyelesaian hubungan industrial, yang dilakukan dengan fihak perantara dengan cara musyawarah mufakat, melalui negosiasi, konsiliasi, dan mediasi untuk win-win solution, dan melalui arbitrase yang menentukan kalah dan menang.

Sengketa, biasanya dalam bidang ilmu hukum dimasukkan ke dalam bidang keperdataan, seperti hukum keluarga, hukum waris, hukum perjanjian, termasuk hukum lingkungan hidup. Dalam lapangan hukum perdata, jika salah satu fihak melakukan suatu tindakan atau pelanggaran yang menimbulkan kerugian bagi fihak lain, maka dengan adanya pelanggaran terhadap hak-hak seseorang terutama yang menimbulkan kerugian, naik dalam bentuk materil maupun immaterial dan fihak yang merasa dirugikan itu tidak rela, iaakan berusaha untuk mengembalikan kerugian tersebut.

Alternatif Penyelesaian Sengketa (APS) merupakan terjemahan dari Alternative Dispute Resolution (ADR), upaya menyelesaikan konflik di luar sistem peradilan, memainkan peranan yang makin besar saat ini. Menurut Nader telah merumuskan sebuah kritik tajam atas antusiasme yang agak membabi buta terhadap bentuk-bentuk penyelesaian konflik seperti itu, yang berdasarkan sebuah analisis terhadap konstelasi kekuasaan yang terlibat dalam bidang baru penyelesaian konflik ini. Jika sistem pengadilan (internasional) yang utuh biasanya dipandang sebagai puncak dari kebudayaan, sekarang ini ADR, dengan beragam cara, disebut sebagai sebuah cara yang paling beradab dari penyelesaian suatu konflik. Ideologi baru ini, kata Nader, berfungsi untuk mengkonsolidasi hegemoni negara-negara industri, khususnya Amerika Serikat.

Penyelesaian sengketa melalui non litigasi yang dikenal juga dengan konsep ASR atau APS). ADR/APS merupakan lembaga penyelesaian sengketa melalui prosedur yang disepakati para fihak, yakni penyelesaian di luar pengadilan dengan cara arbitrase, konsultasu, negoisasi, mediasi, komsiliasi atau penilaian ahli (Pasal 1 poin 10 UU No. 30 Tahun 1999 tentang Arbitrasi dan APS).

Ada kelompok-kelompok penduduk asli dan perwakilan-perwakilan mereka mencoba untuk mengembangkan bentuk-bentuk yang "asli" dalam mengelola hutan, tanah dan air tropis, dan menuntut pengakuan bagi hak-hak komunal lokal. Pokok-pokok pengertian tentang partisipasi, pemerintahan sendiri, pemerintahan yang baik dan berkesinambungan, yang berkembang dalam hukum dan administrasi internasional,memainkan peranan penting dalam diskusi-diskusi dalam hal ini.

Ketika aturan yang dikembangkan oleh masyarakat tersebut kemudian berhadap-hadapan dengan kepentingan pemilik modal yang biasanya mendapat dukungan dari negara (karena proses pemberian ijin pengelolaan lahan dan sumber daya alam yang terkandung di dalamnya), aka nada diffuse, kompetisi dan korporatif dalam penyelesaian sengketanya. Kasus yang awalnya merupakan sengketa keperdataan, berubah menjadi masalah tindak pidana. Upaya yang awalnya ada mempertanyakan, melaporkan atau mengadu ke berbagai lembaga yang berwenang, mengjaukan gugatan keperdataan ke pengadilan hingga pada pemblokiran jalan, perusakan dan atau pembakaran hingga pada membangun aliansi dengan lembaga swadaya masyarakat (LSM). 
Tak jarang pula, warga atau para pendampingnya menjadi tersangka atau terpidana, atau paling tidak menjadi daftar pencarian orang.

\section{2) Pengakuan dan Pemberian Ruang Terhadap Aturan Adat oleh Negara}

Selama ini masalah pengelolaan dan pemanfaatan sumber daya alam (SDA) selalu dicitacitakan, ditujukan dan diperuntukkan untuk kesejahteraan dan atau kemakmuran yang sebesarbesarnya bagi rakyat Indonesia. Cita-cita luhur tersebut tertuang dalam konstitusi Negara Indonesia, khususnya Ps 33 ayat (3) Undang-Undang Dasar (UUD) 1945. Sumber daya alam, berdasarkan penjelasan dari UUD 1945 merupakan pokok-pokok kemakmuran rakyat, dan dipergunakan sebesar-besarnya (untuk) kemakmuran rakyat.

Sebagai tindak lanjut di dalam aturan pelaksananya setingkat undang-undang, dalam hal pengelolaan dan pemanfaatan SDA (khususnya mengenai sumber daya alam kehutanan) diberikan kewenangan kepada negara untuk kemakmuran yang sebesar-besarnya bagi rakyat, misalnya UU No. 5 Tahun 1960 tentang UU Pokok Agraria (UUPA) maupun UU No. 41 Tahun 1999 tentang Kehutanan (UU Kehutanan).

Selanjutnya UUPA juga mengakui dan menghormati hak ulayat dan hak masyarakat adat serta hukum adat. Dalam hukum agraria yang berlaku atas bumi, air dan ruang angkasa ialah hukum adat, sepanjang tidak bertentangan dengan kepentingan nasional dan Negara yang berdasarkan atas persatuan bangsa, dengan sosialisme Indonesia serta dengan peraturanperaturan yang tercantum dalam Undang-undang ini dan dengan peraturan perundangan lainnya, segala sesuatu dengan mengindahkan unsur-unsur yang bersandar pada hukum agama (Pasal 3 dan 5 UUPA).

Harapan terhadap konsistensi cita-cita Negara untuk mensejahterakan rakyatnya melalui pengelolaan dan pengaturan SDA mulai diragukan manakala kita membaca secara cermat dan detail dari kedua undang-undang utama dan selanjutnya beberapa peraturan perundangundangan yang secara khusus mengatur tentang kehutanan. Negara tidak konsisten dengan cita-cita tersebut. Tujuan pengelolaan Negara untuk kemakmuran sebesar-besarnya bagi rakyat Indonesia itu hanya sebatas jargon semata.

Dalam UUPA, substansi undang-undang tentang kepemilikan oleh masyarakat adat (pengakuan hak ulayat dan pengaturan berdasarkan hukum adat) mulai disimpangi dengan pengaturan administrasi. Mekanisme administrasi, yang semula tujuannya hanyalah untuk mempermudah pengakuan dengan bukti-bukti tertulis, justeru menjadi dasar hukum yang kuat untuk kepemilikan lahan yang dapat mengalahkan hak dasar masyarakat, baik sebagai individu maupun berdasarkan hukum adatnya. Hukum administratif mengalahkan hak susbtansi penguasaan tanah bagi rakyat. Misalnya dengan aturan yang menetapkan sertifikasi sebagai alas hak yang paling kuat sebagai bukti kepemilikan. Akibatnya, rakyat akan kehilangan haknya sebagai individu maupun sebagai hak masyarakat adatnya karena masih berbasiskan pada penguasaan yang berketurunan dan saksi-saksi, namun tidak memiliki surat ataupun sertifikat kepemilikan dari negara.

Demikian juga dengan UU Kehutanan, misalnya pasal 38 menyatakan bahwa hutan lindung merupakan kawasan tertutup untuk pertambangan terbuka. Berdasarkan Peraturan Pemerintah Pengganti Undang-Undang (PERPU) No. 1 Tahun 2004, yang selanjutnya telah disahkan menjadi UU No. 19 Tahun 2004, ketentuan pasal 38 UU Kehutanan tersebut dinyatakan tidak berlaku bagi perusahaan pertambangan yang diterbitkan sebelum UU No. 41 Tahun 1999 diterbitkan. UU No. 19 Tahun 2004 ini menggambarkan arogansi pemerintah dalam menetapkan kebijakan kehutanan yang berpihak kepada pemodal. Selain itu, dasar penerbitan dalam bentuk PERPU yang tidak 
memenuhi kondisi dalam keadaan terpaksa, substansinya juga justeru kerusakan hutan pada saat itu (1997-1998 saja kawasan hutan yang rusak 9,75 juta hektar ${ }^{1}$. Seharusnya, PERPU yang disusun adalah moratorium pemanfaatan hasil hutan untuk keperluan komersial dalam jangka waktu tertentu agar hutan dapat bernafas dan memulihkan kondisinya.

Hal lainnya yang diatur masih dalam tingkatan undang-undang adalah pasal-pasal pidana mengenai kejahatan kehutanan yang diatur oleh UU Kehutanan dan UU lain yang materinya juga mengatur kejahatan di kawasan hutan (UU No. 5 Tahun 1990 tentang KSDA dan

Ekosistem dan UU No. 18/2013 tentang Pencegahan dan Pemberantasan Perusakan Hutan. Khusus untuk kejahatan illegal logging, para pelaku yang disebut dengan kejahatan hanya ditujukan kepada rakyat semata. UU ini sedikit mengalami kelemahan dalam membuktikan keterlibatan pelaku utama dan para beking dalam kasus illegal logging. Karena menurut UU Kehutanan, pelaku illegal logging adalah mereka yang dengan sengaja melakukan penebangan, membawa, menguasai dan mengangkut kayu tanpa ijin-ijin yang sah. Semua aktivitas tersebut tidak pernah dilakukan oleh pelaku intelektual atau para beking illegal logging. Perbuatan itu dilakukan oleh buruh tebang, dan pemilik alat angkut. Merekalah yang selalu dijerat dan dihukum.

Pasal 50 UU Kehutanan menyebutkan beberapa pasal yang berkaitan dengan pelarangan yang terjadi pada pengelolaan sumber daya hutan, antara lain menebang tanpa ijin, menebang dekat sumber air (waduk), menebang tidak sesuai ijin menebang di kawasan lindung dan taman nasional, membunuh satwa dan pohon yang dilindungi, menyelundupkan kayu, memproses kayu illegal, menyaup tugas kehuatanan, gagal membayar dana reboisasi dan PSDH.

Selain itu, UU lain yang mengatur tentang kehutanan, yaitu UU No. 5 Tahun 1990 tentang Konservasi Sumber Daya Alam dan Ekosistemnya dalam pasal 19, 21, 22, dan 23 juga menegaskan pelarangan mengenai menebang tumbuhan yang dilindungi, kegiatan yang tidak sesuai dengan fungsi, zona inti dan zona lainnya dari taman nasional, taman hutan raya, dan taman wisata alam, mengangkut kayu yang tidak sesuai dengan ketentuannya, menyimpanmemiliki dan atau memperdagangkan tumbuhan dan satwa yang dilindungi.

Sementara UU No. 18 Tahun 2013 melalui pasal 11 ayat (4) dan pasal 26 justeru menegaskan agar masyarakat di sekitar kawasan hutan, walaupun untuk keperluan sendiri (bukan komersil) harus mendapat ijin dari pejabat yang berwenang. Selain itu juga masyarakat dilarang memindahkan, atau menghilangkan tapal batas Negara, batas fungsi kawasan. Padahal hak masyarakat adat terhadap hutan menjadi kewenangan sendiri yang memiliki alas hak yang kuat. Dalam putusan MK No. 35/PUU-X/2012 tertanggal 16 Mei 2013 menyatakan secara jelas bahwa perumusan hutan adat sama dengan hutan Negara secara hokum tidak berlaku lagi. Mestinya, kedua pasal dalam UU tersebut justeru inkonsisten terhadap konstitusi yang mengakui masyarakat adat dengan segala atribusinya.

Hal lain dari UU No. 18 Tahun 2013 melalui pasal 11 ayat (4) dan pasal 26 justeru menegaskan agar masyarakat di sekitar kawasan hutan, walaupun untuk keperluan sendiri (bukan komersil) harus mendapat ijin dari pejabat yang berwenang. Selain itu juga masyarakat dilarang memindahkan, atau menghilangkan tapal batas Negara, batas fungsi kawasan.

Padahal hak masyarakat adat terhadap hutan menjadi kewenangan sendiri yang memiliki alas hak yang kuat.

Dalam putusan MK No. 35/PUU-X/2012 tertanggal 16 Mei 2013 menyatakan secara jelas bahwa perumusan hutan adat sama dengan hutan Negara secara hokum tidak berlaku lagi. Mestinya, kedua pasal dalam UU tersebut justeru inkonsisten terhadap konstitusi yang mengakui masyarakat adat dengan segala atribusinya. 


\section{3) Pilihan Hukum dan Mekanisme Penyeleasaian Sengketa Menurut Aturan Adat oleh}

\section{Negara}

Demikian pula dengan pilihan hukum dan mekanisme penyelesaian sengketa, walaupun telah dberikan keleluasaan di tingkat undang-undang, namun susbtansi dan mekanismenya justeru dibatasi pada hal-hal tertentu yang hampir dipastikan tidak akan disepakati para pihak, khususnya antara rakyat dengan para pemilik modal (perusahaan).

Pasal 1 angka 25 UU No. 32 Tahun 2009 tentang Perlindungan dan Pengelolaan Lingkungan Hidup (UUPPLH) menjelaskan bahwa sengketa lingkungan hidup adalah sengketa perselisihan antara dua pihak atau lebih yang timbul dari kegiatan yang berpotensi dan/atau telah berdampak pada lingkungan hidup. Selanjutnya, penyelesaian sengketa dapat dilakukan melalui jalur pengadilan atau di luar pengadilan. Pilihan penyelesaian sengketa lingkungan hidup dilakukan secara sukarela oleh pihak yang bersengketa. Gugatan melalui pengadilan hanya dapat ditempuh apabila upaya penyelesaian sengketa di luar pengadilan yang dipilih dinyatakan tidak berhasil oleh salah satu atau para pihak yang bersengketa (Pasal 84 UUPPLH).

Selanjutnya yang dimaksudkan dengan penyelesaian sengketa lingkungan di luar pengadilan dilakukan untuk mencapai kesepakatan mengenai: bentuk dan besarnya ganti rugi, tindakan pemulihan akibat pencemaran dan/atau perusakan, tindakan tertentu untuk menjamin tidak akan terulangnya pencemaran dan/atau perusakan, dan/atau tindakan untuk mencegah timbulnya dampak negatif terhadap lingkungan hidup (Pasal 85 UUPPLH).

Hampir dapat dipastikan bahwa substansi pasal tersebut tidak akan terdapat kesepakatan antara rakyat dengan pelakunya (perusahaan). Akibatnya, maka perkaranya dikembalikan kepada kewenangan pengadilan.

Untuk konteks daerah Aceh. Pemerintah Indonesia melalui UU No. 11 Tahun 2006 tentang Pemerintahan Aceh mengakui keberadaan lembaga-lembaga adat dan aturanaturannya. Bahkan secara khusus telah memberikan kewenangan kepemimpinan adat pada lembaga yang disebut Wali Nanggroe. Pasal 96 UU Pemerintahan Aceh menyebutkan bahwa: Wali Nanggroe merupakan kepemimpinan adat sebagai pemersatu masyarakat yang independen, berwibawa dan berwenang membina dan mengawasi penyelenggaraan kehidupan lembaga-lembaga adat, adat istiadat, dan pemberian gelar/derajat dan upacara-upacara adat lainnya. Selanjutnya yang disebut lembaga adat berfungsi dan berperan sebagai wahana partisipasi masyarakat dalam penyelenggaraan Pemerintahan Aceh dan Pemerintahan

Kabupaten/Kota di bidang keamanan, ketenteraman, kerukunan, dan ketertiban masyarakat (Pasal 98 UU PA). Kemudian lembaga adat yang dimaksud di antaranya adalah Majelis Adat Aceh (MAA).

Sebagai catatan dalam proses ini, bahwa yang disebut masyarakat adat adalah masyarakat yang tumbuh dan berkembang dengan mekanismenya sendiri, di luar mekanisme yang dibuat dan diatur oleh pemerintah. Namun aturan ini sendiri justeru adalah aturan negara

(Qanun) yang membuat aturan tentang lembaga adat di Aceh. Bahwa keberadaan Wali Nanggroe dan Majelis Adat Aceh (MAA) merupakan bentukan pemerintah Aceh tentang adat. Di satu sisi dinyatakan sebagai kepemimpinan adat. Bahkan kedua aturan tersebut menyebutkan MAA sebagai lembaga Adat Aceh (Pasal UU No. 6 Tahun 2011 dan Pasal Qanun nomor 9 Tahun 2008. Padahal status Wali Nanggroe dan MAA dalam masyarakat adat masih menjadi perdebatan yang panjang. 
Demikian juga dengan adanya pengakuan Pemerintah Aceh terhadap aturan hukum adat dalam penyelesaian kasus antara warga masyarakat. Bahkan penyelesaiannya diserahkan ditangani oleh lembaga adat di wilayah terjadinya sengketa atau masalah. Dalam pasal 13

Qanun No. 9 Tahun 2008 tentang Pembinaan Kehidupan Adat dan Adat Istiadat disebutkan:

(1) Sengketa/perselisihan adat dan adat istiadat meliputi:

a. perselisihan dalam rumah tangga;

b. sengketa antara keluarga yang berkaitan dengan faraidh;

c. perselisihan antar warga;

d. khalwat meusum;

e. perselisihan tentang hak milik;

f. pencurian dalam keluarga (pencurian ringan);

g. perselisihan harta sehareukat;

h. pencurian ringan;

i. pencurian ternak peliharaan;

j. pelanggaran adat tentang ternak, pertanian, dan hutan;

k. persengketaan di laut;

I. persengketaan di pasar;

m. penganiayaan ringan;

n. pembakaran hutan (dalam skala kecil yang merugikan komunitas adat);

o. pelecehan, fitnah, hasut, dan pencemaran nama baik;

p. pencemaran lingkungan (skala ringan);

q. ancam mengancam (tergantung dari jenis ancaman); dan

r. perselisihan-perselisihan lain yang melanggar adat dan adat istiadat.

(2) Penyelesaian sengketa/perselisihan adat dan adat istiadat sebagaimana dimaksud pada ayat (1) diselesaikan secara bertahap.

(3) Aparat penegak hukum memberikan kesempatan agar sengketa/perselisihan diselesaikan terlebih dahulu secara adat di Gampong atau nama lain.

Adapun yang dimaksudkan diselesaikan secara bertahap, dalam Pasal 14 Qanun No. 9

Tahun 2008 disebutkan bahwa Penyelesaian secara adat sebagaimana dimaksud dalam Pasal 13 ayat (2) meliputi penyelesaian secara adat di Gampong atau nama lain, penyelesaian secara adat di Mukim dan penyelesaian secara adat di laut.

Pasal ini kemudian ditindaklanjuti dengan Peraturan Gubernur No. 60 Tahun 2013 tentang Pelaksanaan Penyelesaian Sengketa/Perselisihan Adat dan Adat Istiadat yang menjelaskan tentang batasan sengketa/perselisihan ringan sehingga menimbulkan kebingungan dalam penyelesaiannya.

Konflik SDA di Indonesia (khususnya di Aceh), biasanya menyangkut/status tumpang tindih lahan, penyerobotan lahan, besar kecilnya ganti kerugian dan dampak lingkungan yang 
ditimbulkan. Proses penyelesaian biasanya berlangsung lama, melibatkan banyak pihak dan hasilnya pun melebar dari pokok utama persengketaan.

Berdasarkan pengalaman penulis mendampingi masyarakat dalam sengketanya dengan pihak swasta (pemegang konsesi perijinan dan pemerintah), pokok konflik sengketa berawal dari masalah keperdataan status tanah antara masyarakat dengan pemegang hak perijinan (Pertambangan, Kehutanan maupun Perkebunan) berkembang menjadi sengketa antara masyarakat dengan pemerintah. Akhirnya persoalan menjadi peristiwa pidana (penyerobotan lahan, teror, penganiayaan dan pembakaran). Bahkan menjadi isu politik dan hukum bagi pemda, pusat dan DPR-(A/D). Konflik semakin tajam antara pihak keamanan dengan warga. Lalu bertambah kacau karena adanya warga yang berpihak ke perusahaan (mendapat keuntungan pribadi). Sehingga konflik antara sesama warga pun sering tidak dapat dielakkan

Bandingkan juga dengan berbagai kasus yang ada seperti kasus masyarakat Toba, Samosir, Sumut dengan PT IIU (PT. Inti Indorayon Utama).

Berdasarkan kasus-kasus yang ada, konflik antara masyarakat dengan perusahaan jika mengacu pada aturan hukum nasional selalu tidak seimbang. Masyarakat kalah karena masih terbatasnya pemahaman dan wawasan rakyat terhadap strategi, tehnik dan taktik berkonflik atas sumber daya alam, keterbatasan terhadap hukum formal yang berlaku, terbatasnya pemahaman di pihak-pihak yang kuat terhadap berbagai kepentingan yang saling bertentangan serta terbatasnya informasi yang dimiliki rakyat. ${ }^{2}$

Artinya, qanun ini yang mengakui keberadaan hukum adat dan kewenangan untuk menyelesaikan sengketa hanya mengatur tentang sengketa yang berskala kecil, antara warga dengan warga lainnya. Sementara, sengketa antara warga dengan perusahaan merupakan wewenang dari lembaga negara, seperti kepolisian, kejaksaan, dan Pengadilan. Jadi walaupun ada pengakuan dan pengadopsian terhadap aturan adat, namun dibatasi terhadap masalahmasalah kecil yang berkaitan sengketa antara sesama warga.

Demikian juga dengan ada penetapan sanksi adat yang ditetapkan berdasarkan Pasal 16 Qanun No. 9 Tahun 2008, bahwa Jenis-jenis sanksi yang dapat dijatuhkan dalam penyelesaian sengketa adat sebagai berikut:
a. nasehat;
b. teguran;
c. pernyataan maaf;
d. sayam;
e. diyat;
f. denda;
g. ganti kerugian;
h. dikucilkan oleh masyarakat gampong atau nama lain;
i. dikeluarkan dari masyarakat gampong atau nama lain;
j. pencabutan gelar adat; dan
$\mathrm{k}$. bentuk sanksi lainnya sesuai dengan adat setempat.

Keluarga pelanggar adat ikut bertanggung jawab atas terlaksananya sanksi adat yang dijatuhkan kepada anggota keluarganya.

Ketentuan ini lagi-lagi menggambarkan bahwa negara (Pemerintah Aceh) mengatur secara detail tentang adat dan mekanisme penyelesaiannya. Sanksi-sanksi yang ditetapkan tidak 
menggambarkan adanya perkembangan tentang adat dan mekanisme hukum serta sanksi yang akan diterapkan dalam suatu masyarakat adat tertentu.

Qanun ini menggambarkan adanya semangat terhadap pengakuan bagi masyarakat adat, namun terlalu bersemangat sehingga mekanisme dan sanksi-sanksi adat pun diatur oleh pemerintah. Padahal awal dari semangat Qanun ini adalah memberi ruang bagi masyarakat adat untuk mandiri dalam menyelesaikan suatu sengketa di antara para warganya. Selanjutnya, tugas pemerintah adalah turut membantu dan memberikan konsultasi agar masyarakat adat bisa lebih otonom dan menjadi bagian dari penciptaan masyarakat yang aman dan sejahtera dalam kehidupan berbangsa dan bernegara.

\section{C.PENUTUP}

Adanya pengakuan dari pemerintah (nasional maupun daerah) terhadap masyarakat adat, aturan adat dan mekanisme serta sanksinya merupakan suatu realitas adanya pluralisme di Indonesia dan (terutama di Aceh). Dalam kajian peraturan tertulis saja, pengakuan negara tersebut mulai dari konstitusi hingga ke peraturan pelaksananya terjadi ketidak konsistenan. Dari sejumlah aturan daerah di Aceh (Qanun) tentang sumber daya alam, justeru membatasi masyarakat hanya pada kasus-kasus berskala kecil semata. Padahal menurut UUD 1945, bahwa Indonesia mengakui adanya aturan hukum adat sebagai bagian dari sistem hukum di Indonesia. Sehingga, untuk daerah yang menjadi wilayah kepemilikan dan pengelolaan terhadap sumber daya alam masyarakat adat tidak diberikan ruang dalam menyelesaikan kasus sumber daya alam antara warga, baik sebagai individu maupun sebagai komunitas dengan para pemilik modal. Dalam banyak kasus antara warga dengan pemilik modal, maka masyarakat adat diwajibkan hanya menggunakan hukum nasional. Padahal warga sangat minim informasi dan pengetahuan tentang hukum nasional. Jika berharap pada ahli hukum, mereka tidak memiliki biaya. Jikapun ad bantuan hukum gratis, tetap saja masyarakat adat harus menyerahkan hak-haknya kepada pihak-pihak lain tanpa bisa ikut langsung untuk memahami sistem hukum yang ada.

\section{DAFTAR PUSTAKA}

Gokma Toni Parlindungan S, Asas Nebis In Idem Dalam Putusan Hakim Dalam Perkara Poligami Di Pengadilan Negeri Pasaman Sebagai Ceriminan Ius Constitutum, Volume 2, Nomor 1, 2020.

Gokma Toni Parlindungan S, Pengisian Jabatan Perangkat Nagari Pemekaran Di Pasaman Barat Dalam Rangka Pelaksanaan Otonomi Daerah, Ensiklopedia Of Journal, Vol 1 No 2 Edisi 2 Januari 2019,

Harniwati, Peralihan Hak Ulayat Menurut Undang-Undang Nomor 18 Tahun 2004, Volume 1, Nomor 3, 2019.

Jasmir, Pengembalian Status Hukum Tanah Ulayat Atas Hak Guna Usaha, Soumatera Law Review, Volume 1, Nomor 1, 2018. 
Jumrawarsi Jumrawarsi, Neviyarni Suhaili, Peran Seorang Guru Dalam Menciptakan Lingkungan Belajar Yang Kondusif, Ensikopedia Education Review, Vol 2, No 3 (2020): Volume 2 No.3 Desember 2020

Mia Siratni, Proses Perkawinan Menurut Hukum Adatdi Kepulauan Mentawai Di Sebelum Dan Sesudah Berlakunya Undang-Undang Nomor 1 Tahun 1974 Tentang Perkawinan, Ensiklopedia Of Journal, Vol 1 No 2 Edisi 2 Januari 2019,

Remincel, Dimensi Hukum Pelanggaran Kecelakaan Lalu Dan Angkutan Jalan Lintas Di Indonesia, Ensiklopedia Social Review, Volume 1, Nomor 2, 2019.

R Amin, B Nurdin, Konflik Perwakafan Tanah Muhammadiyah di Nagari Singkarak Kabupaten Solok Indonesia 2015-2019, Soumatera Law Review, Volume 3, Nomor 1, 2020. 